REVIEW

\title{
GH/IGF-I and bone resorption in vivo and in vitro
}

\author{
Thor Ueland ${ }^{1,2}$ \\ ${ }^{1}$ Section of Endocrinology and ${ }^{2}$ Research Institute for Internal Medicine, Rikshospitalet University Hospital, N-O027 Oslo, Norway \\ (Correspondence should be addressed to T Ueland; Email: thor.ueland@medisin.uio.no)
}

\begin{abstract}
IGF-I may act as one of several coupling agents by activating bone formation and bone resorption. In vivo studies in normal subjects, postmenopausal women and patients with excess or diminished GH production (acromegaly and GHD) indicate that both GH and IGF-I activate osteoclasts, but that GH has a more pronounced effect, independently of IGF-I. In vitro, GH and IGF receptors have been demonstrated on osteoclasts and both GH and IGF-I may directly modify osteoclast function and activity. In addition to direct effects on osteoclasts, GH and IGF-I may affect bone resorption indirectly by stimulating release of paracrine mediators that regulate osteoclastic resorption (cytokines). Critical for the bone resorptive process is the balance between OPG and RANKL, which is regulated by many systemic factors. In vivo and in vitro, GH/IGF-I may modulate this balance but these studies are difficult to interpret, reflecting the complexity of this system. Increased OPG expression may possibly protect against GH/IGF-I-induced bone resorption and potentially be important for the long-term beneficial effects of GH replacement. Further studies investigating the OPG/RANKL ratio and system in experimental and transgenic GH/IGF models may clarify these issues.
\end{abstract}

European Journal of Endocrinology 152 327-332

\section{Introduction}

Growth hormone (GH) plays a crucial role in the maintenance of bone mass in adults by regulating bone remodeling through a complex interaction of circulating $\mathrm{GH}$, insulin-like growth factors (IGFs), IGF-binding protein (IGFBPs) and locally produced IGFs and IGFBPs, acting in an autocrine and paracrine way. Aging is associated with a decline in trabecular and cortical bone mass and with a deterioration of microarchitecture in both skeletal compartments. Ultimately, the predominant cause of bone loss in postmenopausal women is increased bone resorption without a corresponding increase in bone formation. Serum levels of $\mathrm{GH}$ and IGFs also decline with increasing age (1-3) and a dysfunctional GH-IGF axis may thus play a role in the pathogenesis of postmenopausal osteoporosis. Thus, GH or IGF-I substitution may be considered a treatment option in these patients. While the effects of GH and IGFs on osteoblastic development and function are well documented, studies on effects of $\mathrm{GH}$ and IGFs on bone resorption are relatively scarce. When GH and IGF-I stimulate bone formation, they enhance bone turnover, thereby releasing molecules from activated marrow stromal cells and osteoblasts that also lead to enhanced osteoclastogenesis and mature osteoclast activity. These effects may limit the therapeutic potential of these agents and research aimed at understanding the effects of GH and IGF on osteoclastic resorption may allow the development of better treatment modalities.

\section{In vivo observations in healthy controls and patients with osteoporosis}

Short-term treatment with GH dose-dependently increases biochemical markers of bone resorption in osteopenic postmenopausal women and elderly people $(4,5)$, and these changes are closely correlated with changes in serum IGF-I, suggesting that GH increases osteoclastic activity possibly through increased systemic and/or local IGF-I (5). However, the effects of $\mathrm{GH}$ on bone resorption (and especially bone formation) are blunted in the presence of estrogen in healthy elderly women (6), possibly because estrogen leads to a relative resistance to the stimulatory effect of $\mathrm{GH}$ on IGF-I production or antagonism between estrogen and $\mathrm{GH}$ at the peripheral tissue level as observed in $\mathrm{GH}$ deficiency (GHD) (7). Ebeling et al. (8) demonstrated that treatment of normal women with IGF-I activates both osteoclasts and osteoblasts, but with a more prominent effect on bone formation rather than resorption. Other authors have found similar results, showing that IGF-I to a greater degree stimulates osteoblasts selectively $(9,10)$ and one study found that low 
doses of IGF-I had no effect on bone resorption markers during short-term treatment of elderly women (11). Together, these in vivo data indicate that both $\mathrm{GH}$ and IGF-I activate osteoclasts, but that $\mathrm{GH}$ has a more pronounced effect, independently of IGF-I.

\section{In vivo observations in patients with GH/IGF-I deficiency and excess}

Important information on the effects of GH and IGFs on bone resorption can be investigated in vivo in patient populations characterized by systemic excess or deficiency and the treatment of these. Acromegalic patients have a chronic systemic GH and IGF-I excess and are characterized by increased bone turnover, suggesting activation of both osteoblasts and osteoclasts. Furthermore, biochemical markers of bone formation and bone resorption correlate with circulating GH and IGF-I levels, suggesting that systemic GH and liver-derived IGF-I may have direct effects on both cell types in modulating turnover $(12-17)$. Moreover, normalization of GH/IGF-I levels in these patients during treatment is associated with rapid reductions in turnover markers (16-19). The effect of excess systemic $\mathrm{GH}$ in adult transgenic mice is in accord with findings in these subjects, showing a markedly enhanced bone formation followed by an exaggerated bone resorption, resulting in cortical tissue with inferior mechanical properties (20). In contrast, patients with GHD have secondary osteoporosis characterized by reduced bone mass $(21-24)$, decreased bone turnover measured by biochemical markers, and increased fracture risk (24-26). Treatment of GHD patients with GH dosedependently increases bone turnover and these changes are positively correlated with increases in serum IGFBPs, as well as GH and IGF-I, suggesting that the GH may increase bone mass partly through changes in systemic levels of IGF family members (27). Furthermore, enhanced cortical bone protein and gene expression of IGF-I is found during GH therapy of adult-onset GHD (aoGHD) adults and these changes are correlated with changes in bone matrix gene expression of calcitonin receptor as well as serum biochemical bone markers, indicating direct effects of locally produced IGF-I on osteoclasts and in regulating bone turnover $(28,29)$. Similar effects are found in GHdeficient transgenic mice treated with IGF-I (30).

\section{Effects on osteoclasts in vitro}

In vitro $\mathrm{GH}$ and IGFBP-5 stimulate osteoclastic bone resorption through direct and indirect actions on osteoclast differentiation and through indirect activation of mature osteoclasts, possibly via local IGF-I/II production from osteoblasts $(31,32)$. IGFRI expression has been demonstrated on mature rabbit osteoclasts, as well as human preosteoclasts $(33,34)$, and IGF-I enhances formation of osteoclast-like cells in longterm bone marrow cultures $(35,36)$. In contrast, IGF-I has an inhibitory effect on stimulated bone resorption in bone organ cultures (36). It is believed that IGF-I/II is incorporated into bone matrix through binding to IGFBP-5 and hydroxyapatite for later release during osteoclastic bone resorption. Thus, IGF-I may act as one of several coupling agents by activating bone formation and bone resorption and the amount of IGF-I released from bone matrix should activate a proportionate response from osteoblasts to produce enough osteoid to fill the resorption lacunae.

\section{Effects of GH/IGF-I on immune cells and cytokines}

In addition to direct effects on osteoclasts, GH and IGF-I may affect bone resorption indirectly by stimulating release of paracrine mediators that regulate osteoclastic resorption. Experimental and clinical studies implicate members of the interleukin (IL)-1, IL-6 and tumor necrosis factor (TNF)- $\alpha$ superfamilies in the pathogenesis of postmenopausal osteoporosis. Increased levels of these mediators are associated with enhanced osteoclastogenesis and a negative remodeling balance (3739). In vitro, both $\mathrm{GH}$ and IGF-I increase mouse and human osteoblastic production of IL-6 (40, 41). Furthermore, experimental models show that enhanced $\mathrm{T}$ cell production of TNF resulting from increased $\mathrm{T}$ cell number in the bone marrow is necessary for the increase in osteoclast and the bone wasting induced by ovariectomy $(42,43)$. Both GHR and IGFRI have been demonstrated on human peripheral blood mononuclear cells (44-46) and upon activation may directly stimulate the production of TNF- $\alpha$, IL- 6 and IL- $1 \beta$ from monocytes and macrophages $(47,48)$. Furthermore, IGF-I stimulates the proliferation of human $\mathrm{T}$ cells and activation of IGF-1R by CD28 protects activated T cells from apoptosis $(49,50)$. Finally, enhanced T cell activity has been found when investigating lymphocyte subsets in acromegalic patients (51).

\section{GH/IGF-I and the OPG/RANK/RANKL axis}

Critical for the bone resorptive process is the balance between the newly discovered members of the TNF ligand and receptor superfamilies, osteoprotegerin (OPG) and receptor activator of nuclear factor- $\mathrm{B}$ ligand (RANKL), which mediate the effects of many upstream regulators of bone metabolism (Fig. 1) (reviewed in 52). In vitro experiments show that RANKL stimulates osteoclast differentiation, activates mature osteoclasts, and inhibits osteoclast apoptosis (53-55). In fact, in the presence of macrophage colony stimulating factor (M-CSF) binding to its receptor (c-fms), the ligand is both sufficient and necessary 


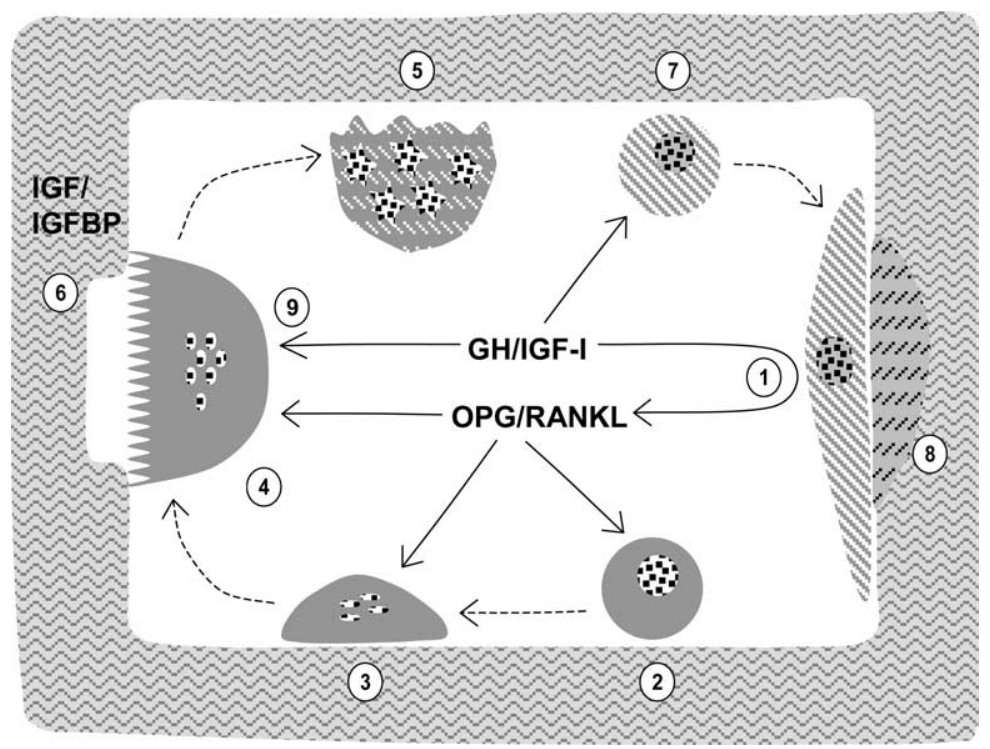

Figure 1 Osteoblastic cells express soluble and membrane-bound RANKL as well as the decoy receptor for RANKL, OPG, upon stimulation with $\mathrm{GH} / \mathrm{IGF}-\mathrm{I}$ (1). Multipotent cells of the macrophagic lineage proliferate into preosteoclasts and differentiate to become pre-fusion osteoclasts (2) when stimulated with M-CSF and RANKL. OPG blocks the effects of RANKL by neutralizing and preventing binding to its receptor RANK. RANKL stimulates fusion into multinucleated osteoclasts (3) and activates them to resorb bone (4). OPG blocks these effects. OPG induces and RANKL prevents apoptosis of mature osteoclasts (5). RANKL-activated osteoclasts may release IGFs stored in bone matrix during bone resorption (6) and these IGFs may promote a population and activity of osteoblasts (7) in proportion to the volume of bone tissue resorbed (8). In addition, GH/IGF-I may directly stimulate osteoclastic function and activity (9).

for osteoclast formation, and thus resorption. The final piece in the system is the receptor for RANKL, which previously was identified on immune cells and named RANK (56). RANK is present on osteoclasts and their precursors and when bound activates several signaling pathways leading to biological activity. OPG blocks the effects of RANKL by neutralizing and preventing binding to its receptor RANK.

Insulin receptor substrates (IRS-1 and IRS-2) are essential for intracellular signaling by insulin and IGF-I, and therefore the anabolic effects of these on osteoblasts. Mice lacking the IRS-1 or IRS-2 gene both exhibit osteopenia by different mechanisms involving osteoblastic regulation of RANKL (57, 58). Whereas IRS-2 - / - mice are characterized by an uncoupling state with decreased bone formation and increased bone resorption, partly due to increased osteoblastic production of RANKL (57), IRS-1 - /mice display a low-turnover osteopenia characterized by decreased bone formation and RANKL-induced bone resorption (58). Hence, IRS-1 and IRS-2 seem to have opposite effects on osteoclastogenesis and RANKL expression in osteoblasts and a concerted regulation of these mediators by IGF-I plays a key role in controlling bone metabolism and maintaining bone homeostasis.

Increased OPG in serum from postmenopausal women was recently reported, suggesting that OPG may be regulated by age-related factors such as GH/IGF-I (59, 60). Moreover, a similar age-related increase in the bone matrix accumulation of OPG in postmenopausal women has been demonstrated, significantly negatively correlated with bone mass in cortical bone, indicating that although OPG is produced in many tissues, bone-derived OPG may be released into the circulation, and serum levels may be a parameter of enhanced activity and turnover in the OPG/RANK/
RANKL system (61). The significance of bone matrix OPG is largely unknown. The increase in serum OPG found in metabolic bone disease may be compensatory to increased osteoclastic bone resorption. Thus, OPG may be released from storage during excess resorption or released from osteoblasts directly to attenuate osteoclastic activity and compensate for increased bone resorption by binding RANKL and blocking RANK activation. Still, OPG does not seem to be a marker of bone turnover since serum OPG levels were normal in patients with acromegaly, as well as GHD (62). Furthermore, no changes in serum OPG were seen during GH substitution in aoGHD women (29) or elderly (63). Another study found increased serum OPG following GH substitution in a mixed population of patients with GHD, negatively correlated to changes in bone turnover (64). In vitro, Rubin et al. (63) found that IGF-I increased RANKL and decreased OPG expression in mouse stromal cells, favoring pro-resorptive activity in vitro. Furthermore, they found that IGF-I treatment to postmenopausal women decreased serum OPG. In contrast, using the same cell line, Gorny et al. (65) found that IGF-I increased OPG expression although the RANKL/OPG ratio increased. These differences observed during in vivo treatment with GH and IGF may have several explanations. First, serum IGF-I was higher in subjects treated with IGF-I compared with GH (63). Secondly, there may be alterations in free IGF-I in the different studies, as GH markedly increases IGFBP-3 (66). Thirdly, the response to GH or IGF-I may differ depending on the population studied (postmenopausal women or GHD). Finally, based on the known effects estrogen has on OPG protein and gene expression in vivo and in vitro $(67,68)$, the effects of estrogen replacement therapy may mask effects of GH/IGF on circulating OPG and explain the unchanged levels in some treatment studies. 
Still, serum levels may not necessarily reflect the cytokine levels in the bone microenvironment and in vitro models may not account for other OPG-regulating cytokines influenced by GH/IGF-I. Thus, increased OPG protein and gene expression has been demonstrated in cortical bone explants following GH substitution, reflecting the in vivo situation locally in bone (28, 29). Nonetheless, increased cortical OPG expression may protect against GH/IGF-I-induced bone resorption and potentially be important for the long-term beneficial effects of GH replacement. Calcitropic hormones, cytokines and growth factors often regulate the expression of both OPG and RANKL from osteoblasts and therefore the ratio of these may ultimately determine the effect of GH/IGF-I on osteoblast-mediated bone resorption. However, this ratio may be difficult to interpret, at least in vivo, for several reasons. Although differences in this ratio may exist in serum from different patient groups, OPG is present in excess on a molar ratio (as is typical for TNF ligands and receptors) making results difficult to interpret. Also, the role of soluble RANKL is unknown as it is the membrane-bound species that is the most potent in regulating osteoclastogenesis. Finally, the influence of TNF-related apoptosis-inducing ligand, a cytotoxic protein that may bind OPG (69), on this equation is unknown. Further studies investigating the OPG/ RANKL ratio and system in transgenic GH/IGF models may clarify these issues.

\section{References}

1 Ravn P, Overgaard K, Spencer EM \& Christiansen C. Insulin-like growth factors I and II in healthy women with and without established osteoporosis. European Journal of Endocrinology 1995132 313-319.

2 Sugimoto T, Nishiyama K, Kuribayashi F \& Chihara K. Serum levels of insulin-like growth factor (IGF) I, IGF-binding protein (IGFBP)-2, and IGFBP-3 in osteoporotic patients with and without spinal fractures. Journal of Bone and Mineral Research 199712 $1272-1279$.

3 Nasu M, Sugimoto T, Chihara M, Hiraumi M, Kurimoto F \& Chihara K. Effect of natural menopause on serum levels of IGF-I and IGF-binding proteins: relationship with bone mineral density and lipid metabolism in perimenopausal women. European Journal of Endocrinology 1997136 608-616.

4 Marcus R, Butterfield G, Holloway L, Gilliland L, Baylink DJ, Hintz RL \& Sherman BM. Effects of short term administration of recombinant human growth hormone to elderly people. Journal of Clinical Endocrinology and Metabolism 1990 70 519-527.

5 Brixen K, Kassem M, Nielsen HK, Loft AG, Flyvbjerg A \& Mosekilde L. Short-term treatment with growth hormone stimulates osteoblastic and osteoclastic activity in osteopenic postmenopausal women: a dose response study. Journal of Bone and Mineral Research $1995 \mathbf{1 0} 1865-1874$.

6 Holloway L, Butterfield G, Hintz RL, Gesundheit N \& Marcus R. Effects of recombinant human growth hormone on metabolic indices, body composition, and bone turnover in healthy elderly women. Journal of Clinical Endocrinology and Metabolism 1994 79 470-479.

7 Burman P, Johansson AG, Siegbahn A, Vessby B \& Karlsson FA Growth hormone (GH)-deficient men are more responsive to $\mathrm{GH}$ replacement therapy than women. Journal of Clinical Endocrinology and Metabolism $1997 \mathbf{8 2} 550-555$

8 Ebeling PR, Jones JD, O'Fallon WM, Janes CH \& Riggs BL. Shortterm effects of recombinant human insulin-like growth factor I on bone turnover in normal women. Journal of Clinical Endocrinology and Metabolism 199377 1384-1387.

9 Grinspoon SK, Baum HB, Peterson S \& Klibanski A. Effects of rhIGF-I administration on bone turnover during short-term fasting. Journal of Clinical Investigation $199596900-906$.

10 Johansson AG, Lindh E, Blum WF, Kollerup G, Sorensen OH \& Ljunghall S. Effects of growth hormone and insulin-like growth factor I in men with idiopathic osteoporosis. Journal of Clinical Endocrinology and Metabolism $1996 \mathbf{8 1} 44-48$.

11 Ghiron LJ, Thompson JL, Holloway L, Hintz RL, Butterfield GE, Hoffman AR \& Marcus R. Effects of recombinant insulin-like growth factor-I and growth hormone on bone turnover in elderly women. Journal of Bone and Mineral Research 199510 $1844-1852$.

12 Bijlsma JW, Nortier JW, Duursma SA, Croughs RJ, Bosch R \& Thijssen JH. Changes in bone metabolism during treatment of acromegaly. Acta Endocrinologica 1983104 153-159.

13 de la PC, Larranaga J, Castro N, Horcajada C, Rapado A, Herrera Pombo JL \& Carbo E. Correlation among plasma osteocalcin, growth hormone, and somatomedin $\mathrm{C}$ in acromegaly. Calcified Tissue International $1988 \mathbf{4 3} 44-45$.

14 Ezzat S, Melmed S, Endres D, Eyre DR \& Singer FR. Biochemical assessment of bone formation and resorption in acromegaly. Journal of Clinical Endocrinology and Metabolism $1993 \mathbf{7 6}$ $1452-1457$.

15 Halse J \& Gordeladze JO. Urinary hydroxyproline excretion in acromegaly. Acta Endocrinologica $1978 \mathbf{8 9} 483-491$.

16 Marazuela M, Astigarraga B, Tabuenca MJ, Estrada J, Marin F \& Lucas T. Serum bone Gla protein as a marker of bone turnover in acromegaly. Calcified Tissue International 199352 419-421.

17 Terzolo M, Piovesan A, Osella G, Pia A, Reimondo G, Pozzi C, Raucci C, Torta M, Paccotti P \& Angeli A. Serum levels of bone Gla protein (osteocalcin, BGP) and carboxyterminal propeptide of type I procollagen (PICP) in acromegaly: effects of long-term octreotide treatment. Calcified Tissue International $1993 \mathbf{5 2}$ $188-191$

18 Fairfield WP, Sesmilo G, Katznelson L, Pulaski K, Freda PU, Stavrou S, Kleinberg D \& Klibanski A. Effects of a growth hormone receptor antagonist on bone markers in acromegaly. Clinical Endocrinology 200257 385-390.

19 Legovini P, De Menis E, Breda F, Billeci D, Carteri A, Pavan P \& Conte N. Long-term effects of octreotide on markers of bone metabolism in acromegaly: evidence of increased serum parathormone concentrations. Journal of Endocrinological Investigation $199720434-438$.

20 Tseng KF \& Goldstein SA. Systemic over-secretion of growth hormone in transgenic mice results in a specific pattern of skeletal modeling and adaptation. Journal of Bone and Mineral Research $199813706-715$

21 Johansson AG, Burman P, Westermark K \& Ljunghall S. The bone mineral density in acquired growth hormone deficiency correlates with circulating levels of insulin-like growth factor I. Journal of Internal Medicine 1992232 447-452.

22 Rosen T, Hansson T, Granhed H, Szucs J \& Bengtsson BA. Reduced bone mineral content in adult patients with growth hormone deficiency. Acta Endocrinologica 1993129 201-206.

23 Holmes SJ, Economou G, Whitehouse RW, Adams JE \& Shalet SM. Reduced bone mineral density in patients with adult onset growth hormone deficiency. Journal of Clinical Endocrinology and Metab olism 199478 669-674.

24 Colao A, Di Somma C, Pivonello R, Loche S, Aimaretti G, Cerbone G, Faggiano A, Corneli G, Ghigo E \& Lombardi G. Bone loss is correlated to the severity of growth hormone deficiency in adult patients with hypopituitarism. Journal of Clinical Endocrinology and Metabolism 199984 1919-1924. 
25 Rosen T, Wilhelmsen L, Landin-Wilhelmsen K, Lappas G \& Bengtsson BA. Increased fracture frequency in adult patients with hypopituitarism and GH deficiency. European Journal of Endocrinology $1997137240-245$.

26 Wuster C, Abs R, Bengtsson BA, Bennmarker M, FeldtRasmussen U, Hernberg-Stahl E, Monson JP, Westberg B \& Witton P. The influence of growth hormone deficiency, growth hormone replacement therapy, and other aspects of hypopituitarism on fracture rate and bone mineral density. Journal of Bone and Mineral Research 200116 398-405.

27 Thoren M, Hilding A, Brismar T, Magnusson P, Degerblad M, Larsson L, Saaf M, Baylink DJ \& Mohan S. Serum levels of insulin-like growth factor binding proteins (IGFBP)-4 and -5 correlate with bone mineral density in growth hormone (GH)-deficient adults and increase with $\mathrm{GH}$ replacement therapy. Journal of Bone and Mineral Research 199813 891-899.

28 Ueland T, Bollerslev J, Flyvbjerg A, Hansen TB, Vahl N \& Mosekilde L. Effects of 12 months of GH treatment on cortical and trabecular bone content of IGFs and OPG in adults with acquired GH deficiency: a double-blind, randomized, placebo-controlled study. Journal of Clinical Endocrinology and Metabolism 2002 $872760-2763$.

29 Ueland T, Odgren PR, Yndestad A, Godang K, Schreiner T, Marks SC \& Bollerslev J. Growth hormone substitution increases gene expression of members of the IGF family in cortical bone from women with adult onset growth hormone deficiency relationship with bone turn-over. Bone $200333638-645$.

30 Behringer RR, Lewin TM, Ouaife CJ. Palmiter RD, Brinster RL \& D'Ercole AJ. Expression of insulin-like growth factor I stimulates normal somatic growth in growth hormone-deficient transgenic mice. Endocrinology 1990127 1033-1040.

31 Guicheux J, Heymann D, Rousselle AV, Gouin F, Pilet P, Yamada S \& Daculsi G. Growth hormone stimulatory effects on osteoclastic resorption are partly mediated by insulin-like growth factor I: an in vitro study. Bone 199822 25-31.

32 Kanatani M, Sugimoto T, Nishiyama K \& Chihara K. Stimulatory effect of insulin-like growth factor binding protein-5 on mouse osteoclast formation and osteoclastic bone-resorbing activity. Journal of Bone and Mineral Research $200015902-910$.

33 Hou P, Sato T, Hofstetter W \& Foged NT. Identification and characterization of the insulin-like growth factor I receptor in mature rabbit osteoclasts. Journal of Bone and Mineral Research 199712 534-540.

34 Fiorelli G, Formigli L, Zecchi OS, Gori F, Falchetti A, Morelli A, Tanini A, Benvenuti S \& Brandi ML. Characterization and function of the receptor for IGF-I in human preosteoclastic cells. Bone 199618 269-276.

35 Hill PA, Reynolds JJ \& Meikle MC. Osteoblasts mediate insulin-like growth factor-I and -II stimulation of osteoclast formation and function. Endocrinology 1995136 124-131.

36 Jonsson KB, Wiberg K, Ljunghall S \& Ljunggren O. Insulin-like growth factor I does not stimulate bone resorption in cultured neonatal mouse calvarial bones. Calcified Tissue International $199659366-370$.

37 Abrahamsen B, Shalhoub V, Larson EK, Eriksen EF, Beck-Nielsen H \& Marks SC Jr. Cytokine RNA levels in transiliac bone biopsies from healthy early postmenopausal women. Bone $2000 \mathbf{2 6}$ $137-145$.

38 Bernard-Poenaru O, Roux C, Blanque R, Gardner C, de Vemejoul MC \& Cohen-Solal ME. Bone-resorbing cytokines from peripheral blood mononuclear cells after hormone replacement therapy: a longitudinal study. Osteoporosis International 200112 $769-776$.

39 Ralston SH, Russell RG \& Gowen M. Estrogen inhibits release of tumor necrosis factor from peripheral blood mononuclear cells in postmenopausal women. Journal of Bone and Mineral Research 19905 983-988.

40 Swolin D \& Ohlsson C. Growth hormone increases interleukin-6 produced by human osteoblast-like cells. Journal of Clinical Endocrinology and Metabolism 199681 4329-4333.
41 Slootweg MC, Most WW, van Beek E, Schot LP, Papapoulos SE \& Lowik CW. Osteoclast formation together with interleukin-6 production in mouse long bones is increased by insulin-like growth factor-I. Journal of Endocrinology 1992132 433-438.

42 Cenci S, Weitzmann MN, Roggia C, Namba N, Navack D, Woodring J \& Pacifici R. Estrogen deficiency induces bone loss by enhancing T-cell production of TNF-alpha. Journal of Clinical Investigation $2000 \mathbf{1 0 6} 1229-1237$.

43 Roggia C, Gao Y, Cenci S et al. Up-regulation of TNF-producing T cells in the bone marrow: a key mechanism by which estrogen deficiency induces bone loss in vivo. PNAS 200198 13960-13965.

44 Janssen JA, Uitterlinden P, Hofland LJ \& Lamberts SW. Insulin-like growth factor I receptors on blood cells: their relationship to circulating total and 'free' IGF-I, IGFBP-1, IGFBP-3 and insulin levels in healthy subjects. Growth Hormone and IGF Research $1998847-54$.

45 Rapaport R, Sills IN, Green L et al. Detection of human growth hormone receptors on IM-9 cells and peripheral blood mononuclear cell subsets by flow cytometry: correlation with growth hormone-binding protein levels. Journal of Endocrinological Investigation $1995 \mathbf{8 0} 2612-2619$.

46 Derfalvi B, Szalai C, Mandi Y, Kiraly A \& Falus A. Growth hormone receptor gene expression on human lymphocytic and monocytic cell lines. Cell Biology International 199822 849-853.

47 Renier G, Clement I, Desfaits AC \& Lambert A. Direct stimulatory effect of insulin-like growth factor-I on monocyte and macrophage tumor necrosis factor-alpha production. Endocrinology $19961374611-4618$.

48 Uronen-Hansson H, Allen ML, Lichtarowicz-Krynska E et al. Growth hormone enhances proinflammatory cytokine production by monocytes in whole blood. Growth Hormone and IGF Research $200313282-286$.

49 Brocardo MG, Schillaci R, Galeano A et al. Early effects of insulinlike growth factor-1 in activated human T lymphocytes. Journal of Leukocyte Biology 200170 297-305.

50 Walsh PT \& O'Connor R. The insulin-like growth factor-I receptor is regulated by CD28 and protects activated T cells from apoptosis. European Journal of Immunology 200030 1010-1018.

51 Colao A, Ferone D, Marzullo P et al. Lymphocyte subset pattern in acromegaly. Journal of Endocrinological Investigation 200225 125-128.

52 Hofbauer LC. Osteoprotegerin ligand and osteoprotegerin: novel implications for osteoclast biology and bone metabolism. European Journal of Endocrinology 1999141 195-210.

53 Lacey DL, Timms E, Tan HL et al. Osteoprotegerin ligand is a cytokine that regulates osteoclast differentiation and activation. Cell $199893165-176$.

54 Yasuda H, Shima N, Nakagawa N et al. Osteoclast differentiation factor is a ligand for osteoprotegerin/osteoclastogenesis-inhibitory factor and is identical to TRANCE/RANKL. PNAS 199895 3597-3602.

55 Takahashi N, Udagawa N \& Suda T. A new member of tumor necrosis factor ligand family, ODF/OPGL/TRANCE/RANKL, regulates osteoclast differentiation and function. Biochemical and Biophysical Research Communications 1999256 449-455.

56 Nakagawa N, Kinosaki M, Yamaguchi K et al. RANK is the essential signaling receptor for osteoclast differentiation factor in osteoclastogenesis. Biochemical and Biophysical Research Communications 1998253 395-400.

57 Akune T, Ogata N, Hoshi K et al. Insulin receptor substrate-2 maintains predominance of anabolic function over catabolic function of osteoblasts. Journal of Cell Biology 2002159 147-156.

58 Ogata N, Chikazu D, Kubota N et al. Insulin receptor substrate-1 in osteoblast is indispensable for maintaining bone turnover. Journal of Clinical Investigation 2000105 935-943.

59 Yano K, Tsuda E, Washida N et al. Immunological characterization of circulating osteoprotegerin/osteoclastogenesis inhibitory factor: increased serum concentrations in postmenopausal 
women with osteoporosis. Journal of Bone and Mineral Research $199914518-527$.

60 Browner WS, Lui LY \& Cummings SR. Associations of serum osteoprotegerin levels with diabetes, stroke, bone density, fractures, and mortality in elderly women. Journal of Clinical Endocrinology and Metabolism 2001 86 631-637.

61 Ueland T, Brixen K, Mosekilde L, Mosekilde L, Flyvbjerg A \& Bollerslev J. Age-related changes in cortical bone content of insulin-like growth factor binding protein (IGFBP)-3, IGFBP-5, osteoprotegerin, and calcium in postmenopausal osteoporosis: a crosssectional study. Journal of Clinical Endocrinology and Metabolism 200388 1014-1018.

62 Ueland T, Bollerslev J, Godang K, Muller F, Froland SS \& Aukrust P. Increased serum osteoprotegerin in disorders characterized by persistent immune activation or glucocorticoid excess - possible role in bone homeostasis. European Journal of Endocrinology $2001145685-690$.

63 Rubin J, Ackert-Bicknell CL, Zhu L, Fan X, Murdry TC, Nanes MS, Marcus R, Holloway L, Beamer WG \& Rosen CJ. IGF-I regulates osteoprotegerin (OPG) and receptor activator of nuclear factorkappaB ligand in vitro and OPG in vivo. Journal of Clinical Endocrinology and Metabolism 200287 4273-4279.

64 Lanzi R, Losa M, Villa I, Gatti E, Sirtori M, Dal Fiume C \& Rubinacci A. GH replacement therapy increases plasma osteoprotegerin levels in GH-deficient adults. European Journal of Endocrinology 2003148 185-191.

65 Gorny G, Shaw A \& Oursler MJ. IL-6 LIF, and TNF-alpha regulation of GM-CSF inhibition of osteoclastogenesis in vitro. Experimental Cell Research 2004294 149-158.

66 Ohlsson C, Bengtsson BA, Isaksson OG, Andreassen TT \& Slootweg MC. Growth hormone and bone. Endocrine Reviews $19981955-79$.

67 Bord S, Ireland DC, Beavan SR \& Compston JE. The effects of estrogen on osteoprotegerin, RANKL, and estrogen receptor expression in human osteoblasts. Bone 200332 136-141.

68 Hofbauer LC, Khosla S, Dunstan CR, Lacey DL, Spelsberg TC \& Riggs BL. Estrogen stimulates gene expression and protein production of osteoprotegerin in human osteoblastic cells. Endocrinology $19991404367-4370$.

69 Emery JG, McDonnell P, Burke MB, Deen KC, Lyn S, Silverman C, Dul E, Appelbaum GR, Eichman C, DiPrinzio R, Dodds RA, James IE, Rosenberg M, Lee JC \& Young PR. Osteoprotegerin is a receptor for the cytotoxic ligand TRAIL. Journal of Biological Chemistry 1998273 14363-14367.

Received 28 September 2004

Accepted 15 December 2004 